Toby Miller:

\title{
The Oldest New Network: The Division of Cultural Labor and its Ecological Impact
}

\begin{abstract}
Perhaps the most basic network in modern life is the division of labor. It certainly rates alongside family, school, and town. That inexorably leads to a discussion of how resources are allocated within this division, who exercizes power, and what happens when the network meets a seemingly natural or unnatural end. For networks that may appear extremely stable can come to abrupt or scheduled conclusions, when a company goes bankrupt or a school cohort breaks up. This article briefly examines the history of the division of labor, with particular reference to culture and to its internationalization, concluding with a brief discussion of how short-term networks can lead to the exploitation of workers and have a devastating ecological impact.
\end{abstract}

\section{Agenda}

The Division of Labor .32

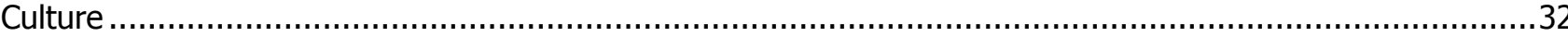

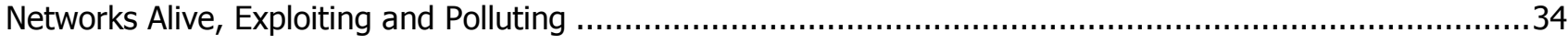

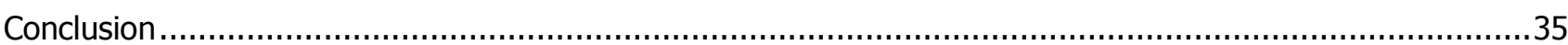

\section{Author}

Toby Miller

- Toby Miller is a Professor in the Department of Media \& Cultural Studies at the University of California, Riverside. He studies the media, sport, labor, gender, race, citizenship, politics, and cultural policy via political economy, textual analysis, archival research, and ethnography. Editor of Television \& New Media and Co-Editor of Social Identities, he also edits the book series Popular Culture and Everyday Life (Lang), and was previously Chair of the International Communication Association Philosophy of Communication Division, Editor of Journal of Sport \& Social Issues, and Co-Editor of Social Text, the Blackwell Cultural Theory Resource Centre, and the book series Film Guidebooks (Routledge), Sport and Culture (Minnesota), and Cultural Politics (Minnesota. He is the author and editor of over 30 books, the most recent of which are Makeover Nation: The United States of Reinvention (2008) and The Contemporary Hollywood Reader (2009). His next book, in press, is Television Studies: The Basics.

疋 +1 (917) 917-7512679, $ه$ tobym@ucr.edu 


\section{The Division of Labor}

In the 14th and 15th centuries, a mercantile system arose from calculations, appropriations, and exchanges of climate, geography, flora, and fauna. Exchanges of goods turned into exchanges of labor. As food commodities made their way around the globe, so did people, often as slaves. When machinery was developed, work split into an industrial mode. Between the 16th and 18th centuries, cities grew into manufacturing sites, populations urbanized, and wages displaced farming as the basis of subsistence (Lang and Hines 1993: 15). These new forms of labor were institutionalized in empire. In the 18th and 19th centuries, manufacturing went on at the centre, with food and raw materials imported from the periphery. In the 20th century, assemblyline control, with its quid pro quo of sufficient wages to buy the products being assembled, became a Fordist paradigm. The labor force was divided between blue-collar workers, who undertook tasks on the line, and white-collar workers, who observed them (Scott 1998: 18).

Differences of opinion emerged about the significance of the balance of trade to a country's wellbeing. Mercantilists thought it should be controlled, but free traders wanted market forces to rule in accordance with factor endowments and an international division of labor. Keynesian responses to the Depression made protectionism a more legitimate position in economic theory, until stagflation emerged from the transnational phase that commenced after the war. By the mid-1980s, offshore production by multinationals exceeded trade between states. Since that time, the global capitalist economy has depended on the integration of production processes; even when geographically dispersed, they remain governed by states and parastatal institutions in the service of capital accumulation. Products are first made and consumed in the centre, in a major industrial economy; then exported to the periphery; and finally produced and consumed "out there," once technology is standardized and savings can be made on the labor front. Goods and services owned and vended by the periphery rarely make their way into the centre as imports.

Hence the idea of a New International Division of Labor (NIDL). This model reveals that developing markets for labor and sales, and the shift from the spatial sensitivities of electrics to the spatial insensitivities of electronics, have pushed businesses beyond treating Third World countries as suppliers of raw materials, to look on them as shadow-setters of the price of work, competing among themselves and with the First World for employment. As production split across continents, the prior division of the globe into a small number of empires and satellites and a majority of underdeveloped countries has been compromised. Folker Fröbel and his collaborators (1980) christened this trend the NIDL. Whereas the old IDL had kept labor costs down through the formal and informal slavery of colonialism (the trade in people and indentureship) and importation of cheap raw materials with value added in the metropole, successful action by the working class at the centre redistributed income. The response from capital was to export production to the Third World, focusing increasingly on young women workers. China is the contemporary epitome of the NIDL at work.

\section{Culture}

So how does the division of labor fit with culture? Artists, musicians, poets, and scholars traveled across royal courts, salons, and universities for many centuries prior to capitalism. But that revolution in social relations in Europe and the US was accompanied by a new method and history to the exchange of bodies, ideologies, images, and money. Culture, which had previously referred to tending land, came to personify instrumentalism at the same time as negating it; on the one hand, there was the industrialization of agriculture; on the other, the tutoring of individual taste. German, French, and Spanish dictionaries of the 18th century indicate a shift in the meaning of culture towards spiritual cultivation and away from animal husbandry. With the spread of literacy and publishing, and the advent of customs and laws that were shared, administered, and understood through the printed word, cultural texts supplemented and supplanted physical force as sources of authority. As the Industrial Revolution moved populations to cities, food was imported and new textual forms were exchanged, for both practical and entertainment purposes. Along came a society of consumers and an art world. There was an obvious corollary in labor terms: the emergence of poligrafi in 15th century Venice, and hacks in 18th century London. They wrote popular books about correct forms of conduct-instructions on daily life (Briggs and Burke, 2003). Thus began a division of cultural labor in the modern sense.

With the First World losing manufacturing jobs because of the NIDL from the 1970s, culture be- 
came a core employment site in the Global North. Most new jobs within the First World now come from the culture and media sector. Their connection is knowledge, information, emotions, and communication (Hardt and Negri 2000: 285). Daniel Bell discerns four changes in the Global North's economy from production to services:

- the preeminence of professionalism and technique

- the importance of theory to innovate and generate public policies

- the formation of a discourse of the future; and

- new intellectual technologies that help make decisions (Mattelart 2003: 77-78)

This is a technocratic vision dominated by experts, a world of modernity, of rationality, of the ability to apply reason to problems, and seek salvation in the secular. It favors ecological metaphors to describe workspaces, emptying out the core environmental impact on nature of industry at the same time as it denies the solidarity and security of ongoing employment. Manuel Castells suggests we inhabit an epoch of networks of knowledge workers, effectively a ruling class operating through technique and technology. This is not the daily society of humanity, but a society, after Gilles Deleuze and Félix Guattari, of control (Mattelart 2003: 143). Castells discerns two economic models at work here. In the first system, the Anglo-Saxon one, services substitute for manufactures, with finance displacing physical labor. The second model, from Japan and Germany, combines the two, rather than substituting one for the other (Hardt and Negri 2000: 286). For their part, Michael Hardt and Antonio Negri develop the idea of immaterial labor to describe the tendency to exchange information, knowledge, and emotion, filtered through the computer and its methods of invigilation, and abstracted from physical work (2000: 290-92). While this notion of immaterial labor captures the realities of work in the postindustrial sector, it is awkwardly close to forgetting the fundamental ecology of the division of laborthat this is not a network of equality, but domination, and one that imperils the Earth.

Using typologies from Fritz Machlup and Armand Mattelart, I propose the following types of paid cultural and media workers:

- $\quad$ creators, who make new art and ideas

- transmitters, who communicate the art and ideas of others
- transformers, who change art and ideas via form

- processors, who change art and ideas via formats

- interpreters, who change art and ideas via idiom; and

- analysts, who create new interpretations (Mattelart 2003: 63)

Within the culture industries we find the following groups of workers, albeit with much overlap:

- creators, such as musicians, directors, writers, journalists, and technical workers

- artisans, including sound engineers, editors, cinematographers, and web designers

- impresarios, who connect proprietors and executives to creators

- proprietors and executives, who control employment and investment and negotiate with states; and

- $\quad$ audiences, whose labor as workers pays for content, whose labor as interpreters gives it meaning, and whose labor as imaginary people is its alibi

These groups operate within institutional contexts, specifically:

- $\quad$ private bureaucracies, controlling investment and distribution

- $\quad$ public bureaucracies, offering what capitalism cannot

- $\quad$ small businesses, run by charismatic individuals; and

- $\quad$ networks, fluid associations formed to undertake specific projects

Private bureaucracies continue to control most of the cultural/copyright industries, but very frequently in collaboration with less formal networks, while public bureaucracies experience pressure to comport themselves in an ever-more commercial manner.

Since the demise of the production-line, carassembly-like Hollywood studio-system of production that applied between about 1920 and 1970, but was eroding by the late 1950s, the US film industry has been a pioneer in the loose model of employment beloved of contemporary management. Jobs are constantly ending, starting, and moving. Hollywood exemplifies 'flexible specialization,' a shift from life-long employment to casual labor. It has an economic commitment to 'permanent innovation,' 
and a political commitment to control its environment (Piore and Sabel 1984: 17).

Workers and bosses strike complex, transitory arrangements on a project basis via temporary organisations, with small numbers of divers hands involved at each stage other than production, when sizeable crews function both together and semiautonomously. Places and networks matter in terms of textual cues, policy incentives, educational support, financing, and skills. Time matters because of cost and marketing. Work may be subject to local, national, regional, and international fetishization of each component, matching the way that the labor undertaken is largely fetishized away from the final text. Conventional organizational charts are inadequate to the task, especially if one seeks to elude the conventions of hierarchy through capital whilst recognizing the eternal presence of managerial surveillance. Business leeches want flexibility in the numbers they employ, the technology they use, the place where they produce, and the amount that they pay-and inflexibility of ownership and control (Eisenmann and Bower, 2000).

There were 3,500 film and television companies in Southern California in 2002. Perhaps $0.1 \%$ of them hired over a thousand people, while about $75 \%$ had no more than four employees (Miller et al., 2005). This makes the industry seem dispersed, and has led to theorizations of it as an open ecological system. But the power and logic of domination by a small number of vast entities is achieved via a huge globalizing network of subcontracted firms and individuals, in turn mediated through unions, employer associations, education, and the state. Movie capital is footloose in its networking, and destructive in its ecology, as the case studies below will illustrate.

\section{Networks Alive, Exploiting and Polluting}

Mexico became a key site for offshore Hollywood production following the success of Titanic (James Cameron, 1997). During the film's production, the national film studio Churubusco was renovated and a National Film Commission established, with satellites across the country's 31 states, offering Hollywood moguls everything from trips in governors' helicopters to many other, less exotic, services. Mexico's new film „union” set up shop in Los Angeles to reassure industry mavens of its cooperativeness and to remain up-to-date on US pay rates-in order to undercut them. Not surprisingly, Rupert Murdoch cites approvingly the number of European workers invisibly employed in the making of Titanic. 'this cross-border cultural co-operation is not the result of regulation, but market forces. It's the freedom to move capital, technology and talent around the world that adds value, invigorates ailing markets, creates new ones.' National Public Radio reported that Rupert's very own Fox company was asking the Mexican Government to offer further financial incentives for runaways even as the privatization of the film industry during the 1990s had decimated local production. Overall, the present conjuncture is a screen testimony to the North American Free Trade Agreement, which has seen the average number of offshore productions in Mexico per year increase from seven to seventeen as the shipment of film stock and special-effects equipment is facilitated, especially for low-budget productions while local production spiraled downwards, from 747 films in the decade prior to the Treaty, to 212 in the decade since (Maxwell and Miller, 2006).

Restoring Mexico to the Hollywood map gained James Cameron the Order of the Aztec Eagle from a grateful government, which offers docile labor, minimal bureaucracy, a weak peso, many US-trained technicians and liaison services. The National Film Commission's web site states that almost 3,000 foreign productions were shot there between 1995 and 2002, from airline commercials to feature films (Maxwell and Miller, 2006).

But there is a cruel irony to the globalization of cultural labor through loose networks: people submerged at the end of the credits (or not listed at all) "owed" their livelihoods to a boat sunk by invisible ice and business hubris. The village was cut off from the sea and local fisheries by a walled 'movie maquiladora' built to keep them away from production. Fox's chlorination of surrounding seawater decimated the ranks of sea urchins, which Popotla had long fished, and reduced overall fish levels by a third. Meanwhile, it was revealed that the overall cost of the film could have provided safe drinking water to 600,000 people for a year. (Miller et al. 2005: 165). The Popotlanos demonstrated their environmental consciousness by decorating the wall with rubbish to ridicule the filmmakers and call for mariscos libre (freedom for shellfish) (for photos, see rtmark.com/popotlaimages.html).

Fox again ran into difficulties while making The Beach (2000) in Thailand's Maya Bay, part of Phi Phi Islands National Park, where a (textually) modern- 
day Eden suddenly turns nasty for jaded tourists. Thai environmental and pro-democracy activists publicized the arrogant despoliation they experienced. Natural scenery was bulldozed because it did not fit the company's fantasy of a tropical idyll: sand dunes were relocated, flora rearranged, and a "new" strip of coconut palms planted. The producers paid off the government with a donation to the Royal Forestry Department, and campaigned with the Tourism Authority of Thailand to twin the film as a promotion for the country. Meanwhile, the next monsoon saw the damaged sand dunes of the region collapse, its natural defenses against erosion destroyed by Hollywood bulldozers. All the while, director Danny Boyle claimed the film was „raising environmental consciousness" among a local population that was allegedly "behind" US levels of „awareness” (Miller et al. 2005).

\section{Conclusion}

We inhabit a world where flexibility is the mega-sign of affluence, and precariousness its flipside. One person's calculated risk is another's burden of labor, inequality is represented as the outcome of a moral test, and the young are supposed to regard insecurity as an opportunity rather than a constraint.

Antonio Negri (2007) refers to people mired in contingent media work as the cognitariat, because they have high levels of educational attainment, and great facility with cultural technologies and genres. The cognitariat plays key roles in the production and circulation of goods and services, through both creation and coordination. Today's 'culturalisation of production' may enable these intellectuals, by placing them at the center of world economies, but it also disables them, because it does so under conditions of flexible production and ideologies of "freedom." This new proletariat is not defined in terms of factories, manufacturing, or opposition to rulingclass power and ideology. Indeed, it is formed from those whose immediate forebears, with similar or less cultural capital, were the salariat, and confident of guaranteed health care and retirement income. It lacks both the organization of the traditional working class and the political entrée of the old middle class.

What used to be the fate of artists and musicianswhere "making cool stuff" and working with relative autonomy was meant to outweigh ongoing employment-has become a norm across virtually every sector of the economy. The outcome is contingent labor as a way of life-the triumph of a New Inter- national Division of Cultural Labor. The results are even worse for the unskilled labor of those who are outside the cognitariat, like many Popotlanos and Thais. It is a timely reminder for those who fetishize the supposedly new "creative" industries or the information society and economy that it repeats many of the humanly exploitative and environmentally disastrous escapades of smoky industrialism.

There would be no culture, no media, without labor. It is the beating heart of creativity and social justice. When it is reduced to the contingency of network metaphors, it becomes precarious. And when ecological ideas are removed from their explanation of the environment, that precariousness produces an eternal pollution.

\section{References}

Briggs, Asa and Peter Burke. (2002). A Social History of the Media: From Gutenberg to the Internet. Cambridge: Polity Press.

Eisenmann, Thomas R. and Joseph L. Bower. (2000). "The Entrepreneurial M-Form: Strategic Integration in Global Media Firms." Organization Science 11, no. 3: 348-55.

Fröbel, Folke, Jürgen Heinrichs, and Otto Kreye. (1980). The New International Division of Labor. Trans. P. Burgess. Cambridge: Cambridge University Press.

Hardt, Michael and Antonio Negri. (2000). Empire. Cambridge, Mass.: Harvard University Press.

Lang, Tim and Colin Hines. (1993). The New Protectionism: Protecting the Future Against Free Trade. New York: New Press.

Mattelart, Armand. (2003). The information Society: An Introduction. Trad. Susan G. Taponier and James A. Cohen. London: Sage Publications.

Maxwell, Richard and Toby Miller. (2006). „Film and Globalization." Communications Media, Globalization and Empire. Ed. Oliver Boyd-Barrett. Eastleigh: John Libbey Publishing. 33-52.

Miller, Toby, Nitin Govil, John McMurria, Richard Maxwell, and Ting Wang. (2005). Global Hollywood 2. London: British Film Institute.

Negri, Antonio. (2007). goodbye mister socialism. Paris: Seuil.

Piore, Michael J. and Charles F. Sabel. (1984). The Second Industrial Divide: Possibilities for Prosperity. New York: BasicBooks.

Scott, Allen J. (1998). Regions and the World Economy: The Coming Shape of Global Production, Competition, and Political Order. Oxford: Oxford University Press. 